\title{
Income inequality and partisan voting in the United States*
}

\author{
Andrew Gelman, Columbia University \\ Lane Kenworthy, University of Arizona \\ Yu-Sung Su, Columbia University and New York University
}

9 February 2010

\footnotetext{
* Andrew Gelman, Dept of Statistics and Dept of Political Science, Columbia University; Lane Kenworthy, Dept of Sociology and School of Government and Public Policy, University of Arizona; Yu-Sung Su, Applied Statistics Center, Columbia University, and Steinhardt School of Education and Human Development, New York University. The authors will share all data and coding information with those wishing to replicate the study.

Direct all correspondence to Andrew Gelman, gelman@stat.columbia.edu

This article was prepared for a special issue of Social Science Quarterly on the topic of "Inequality and Poverty: American and International Perspectives." We thank the U.S. National Science Foundation and Institute for Educational Sciences for partial support of this research.
} 


\title{
Income inequality and partisan voting in the United States
}

\begin{abstract}
Objectives: Income inequality in the United States has risen during the past several decades. Has this produced an increase in partisan voting differences between rich and poor? Methods: We examine trends from the 1940s through the 2000s in the country as a whole and in the states. Results: We find no clear relation between income inequality and class-based voting. Conclusions: Factors such as religion and education result in a less clear pattern of class-based voting than we might expect based on income inequality alone.
\end{abstract}

The Republicans are traditionally the party of the business establishment, while the Democrats represent labor. Even to the extent the Democratic Party represents established interests-for example, government employees, teachers, and others on the public payroll-they tend to be lower income than comparable Republican-leaning business groups. As McCarty, Poole, and Rosenthal (2006) point out, economic inequality has implications for class-based voting. All else being equal, the greater the inequality, the more the economic interests of the rich and poor should diverge, and the more one would expect to find such groups at home in opposing political parties.

Recent decades have seen a striking rise in income inequality in the United States (Gottschalk and Danziger, 2005; Piketty and Saez, 2007; Mishel, Bernstein, and Shierholz, 2009). Has this led to an increase in partisan voting differences between rich and poor?

We offer no sweeping story here. Instead we share some statistical observations on inequality and voting over time in the country as a whole and in the states, revealing patterns that suggest complex connections between inequality, geography, and partisan voting in the United States.

\section{Do the rich and the poor vote differently?}

We begin with a key descriptive fact: there are sharp differences in partisan voting by income. In national elections, richer individuals are more likely to vote Republican. This difference has persisted with few exceptions since the New Deal era.

This will come as a surprise to some, who observe the recent pattern of Republican presidential candidates faring best in poor states and infer that perhaps poor persons are now as or more likely than the rich to vote Republican. Gelman et al. $(2007,2009)$ resolve this apparent paradox. Using multilevel modeling to explore the patterns of income and voting within and between states, they find that different states show different patterns of partisan voting by income. In poor states such as Mississippi, richer people are much more likely than poor people to vote Republican, whereas in rich states such as Connecticut, there is very little difference in vote choice between the rich and the poor. This trend has gradually developed since the early 1990s and has reached full flower in the elections of 2000 and beyond. As a result, richer states now tend to favor the Democratic candidate, yet in the nation as a whole richer people remain more likely than poorer people to vote Republican. 
How much more likely? In presidential elections, the share voting Republican has tended to be 5 to 20 percentage points higher among voters in the upper third of the income distribution than among voters in the lower third.

Figure 1 shows this rich-poor voting difference as estimated using national survey data for each presidential election from 1940 to 2004. It displays the share voting Republican among the top income third minus the share among the lower income third. In the 1940s the difference hovered around 20 percentage points. In the elections from 1952 through 1972 it shrank to around 5 percentage points. Since 1976 the difference has returned to nearly 20 percentage points.

Figure 1 about here

These trends over time have been similar throughout the country, although the absolute difference has been larger in the south than elsewhere (Figure 2). This difference between rich and poor holds among voters of all races (Figure 3). The same is true of most religious groups, though Jews and "no religion" are exceptions (Figure 4). Much has been made of Barack Obama's recent success among highly-educated voters, but as E. J. Dionne (2005) has observed, the Democrats' strength among well-educated voters is strongest among those with household incomes below $\$ 75,000$ - "the incomes of teachers, social workers, nurses, and skilled technicians, not of Hollywood stars, bestselling authors, or television producers, let alone corporate executives." The rich-poor voting difference also holds in congressional elections, both in the south as well as in the rest of the country (Figure 5).

Figure 2 about here

Figure 3 about here

Figure 4 about here

Figure 5 about here

\section{Income inequality and the rich-poor partisan voting gap over time}

\section{The country as a whole}

Has the rise in income inequality over the past generation had an impact on income-based partisan voting? Let's first consider data for the country as a whole. Figure 2 shows two time trends for income inequality. The first chart uses data from the Current Population Survey (CPS) on the pretax incomes of families. Inequality is measured as the ratio of income at the 80th percentile of the distribution to income at the 20th percentile. These data are by far the most frequently referenced in analyses of inequality, and the 80/20 ratio is a reasonably common measure (see, e.g., Bartels, 2008). Thomas Piketty and Emmanuel Saez have analyzed tax records to generate an alternative estimate of income inequality. They calculate the share of total pretax income going to the top $10 \%$ of taxpaying units. These data are shown in the second chart in Figure 6.

Figure 6 about here

Both measures suggest that income inequality was lower in the 1950s, 1960s, and early 1970s than it had been in the late 1940s. The CPS data on family incomes begin in 1947, so they offer no insight into prior levels. The Piketty-Saez data suggest that the decline in inequality was quite 
sharp. The high level of income inequality in the early 1940s was not, according to these data, a temporary fluke; inequality had been high since the 1920s (not shown here).

Both data series also indicate a sharp increase in income inequality beginning in the 1970s or 1980s. The CPS data suggest that the rise started at some point in the 1970s, while the PikettySaez data suggest it began in the early 1980s.

For the nation as a whole, then, there is broad similarity between the trends in income inequality and in the rich-poor gap in partisan voting. Each declined after the 1940s and then rose beginning in the 1970 s or 1980 s. The simple correlation between inequality and the richpoor vote gap is 0.5 using the CPS inequality data and 0.4 using the Piketty-Saez inequality data.

\section{Patterns within states}

It would be injudicious to draw an inference about causality from the national correlation over time. Many things were distinct about the 1950s, 1960s, and early 1970s: rapid economic growth coupled with modest levels of unemployment and inflation, steadily rising wages and living standards in the lower half of the income distribution, a tacit accord between large firms and labor unions, a renewed sense of national unity following the end of the Depression and the victory in World War II, and others. Any or all of these may have contributed to both declining income inequality and a reduction in the partisan voting gap between high- and low-income voters.

Variation across the states offers added analytical leverage. The states vary widely in the degree to which income inequality has changed over time. Using the CPS data (the Piketty-Saez tax data are not available for individual states), we can calculate an 80/20 ratio for each state in each year beginning in 1963. Over the ensuing four decades, inequality declined or held steady in some states, increased moderately in others, and rose substantially in others.

Have these varying inequality trajectories produced corresponding trends in income-based partisan voting? To find out, we need state-level data on the difference in Republican voting between high- and low-income voters. For the 2000 and 2004 elections, the sample sizes for individual states in the National Annenberg Election Survey are large enough to generate reliable estimates. Before 2000 the best available data are from the National Election Studies (NES), and for most states the sample sizes are too small to learn much for individual elections. We therefore pool the data across multiple election years. We use three periods: 1952 to 1972,1976 to 1996 , and 2000 to 2004 . The first of these, 1952-72, is characterized by comparatively low income inequality. The latter two periods feature higher inequality. We separate 1976-96 from 2000-04 because of the differing data sources.

We further pool the states into three groups according to their pattern of change over time in income inequality. One group (21 states) experienced a decline or no change in inequality between the 1952-72 period and subsequent years. The second group (17 states) experienced a moderate rise in inequality. In the third group (11 states) inequality rose sharply.

We generate an estimate of the income-based voting gap in each of these three groups in the presidential elections in each of the three periods. Figure 7 plots the pattern of income inequality and income-based voting for each of the three groups of states.

Figure 7 about here 
These three charts are inconsistent with the hypothesis that income inequality is a key determinant of the rich-poor partisan voting gap. During the first time period, from 1952 to 1972, the voting gap was relatively small in all three groups of states, ranging from zero to about 5 percentage points. Despite sharply differing trends in income inequality across the three groups, the voting gap then jumped to around 15 percentage points in the 1976-96 period in each of the three. In the first group (left chart) income inequality fell slightly on average; in the second (middle chart) it rose modestly; in the third (right chart) it increased sharply. But each group of states experienced a similar rise in the rich-poor partisan vote gap. Developments between 197696 and 2000-04 data further contradict the hypothesis, as the group with the largest rise in income inequality (group 3) experienced the largest decrease in the rich-poor voting gap.

\section{Variation between states}

Historically, inequality in the United States has had a significant geographical component; in addition to inequality between households within states, there is considerable inequality between states. Consider Connecticut and Mississippi, a relatively rich state and a relatively poor one. In 1965, the household income at the 80th percentile of Connecticut's income distribution was approximately $\$ 30,000$ (in 2004 dollars). The income level at Connecticut's 20th percentile was $\$ 15,000$. In Mississippi the income at the 80th percentile in that year was only $\$ 16,000$. In other words, a low-income household in Connecticut had virtually the same income as a relatively high-income household in Mississippi.

If people evaluate their incomes using a nationwide frame of reference, many people in Connecticut in 1965 may have thought of themselves as high-income, while a large share of Mississippi's population may have perceived themselves as low-income. If so, and if income inequality affects partisan voting differences between the rich and the poor, we would expect a high degree of income inequality among the states to result in a large gap between rich states and poor states in partisan voting. The larger the gap in average income across states, the more likely rich states should be to vote Republican and the less likely poor states should be to do so.

Inequality between states in average income has decreased over the past half century, as Figure 8 shows. The relative positions of states have not changed much; states that were poorer in the 1940s, such as Mississippi, tend to remain at the low end. But from 1940 to around 1980 average income grew faster in poorer states, so the degree of between-state inequality fell. Since 1980 the gap has held constant. Figure 9 offers another way to see this.)

Figure 8 about here

Figure 9 about here

Given these trends, we might expect a reduction in between-state differences in partisan voting in the period leading up to 1980 and then little or no change after 1980. In fact, as Gelman et al. (2007, 2009) document, this is not at all what happened. There was little systematic pattern prior to 1990 . Then, beginning in the 1990s, we observe rich states moving steadily away from the Republicans.

As noted earlier, Gelman et al. find that this latter trend is mainly a product of upper-income voters in rich states shifting from Republican to Democratic. Figure 10 shows the difference in Republican voting, comparing people in rich and poor states, from the 1950s through the present decade. Before the 1990s, rich and poor states had very little difference, on average, in their political complexions. But the past two decades have witnessed a divergence, with the largest 
changes occurring among voters in the upper third of the income distribution. This is also true if the analysis is restricted to white voters (Figure 11).

Figure 10 about here

Figure 11 about here

This is even more surprising for a material self-interest perspective on voting because highincome voters in rich states have enjoyed particularly rapid income gains during the past two decades. Figure 12 shows trends in real incomes at the 90th and 10th percentiles in each state. The states are ordered from richest to poorest. Not only are the 90th-percentile incomes in rich states higher than those of their counterparts in poor states, but they have grown very rapidly in recent years. Yet these people have increasingly voted Democratic.

Figure 12 about here

Abramowitz and Teixeira (2008) have written of "the rise of a mass upper middle class," and this is what we are seeing in Figure 5. Whether you call it red and blue America, or soccer moms versus SUV dads, it is a geographic component to the culture war that was not occurring in the days of Spiro Agnew and Richard Nixon, or even in the era of Phyllis Schlafly and Ronald Reagan.

\section{The U.S. compared to other countries}

Using international survey data, Huber and Stanig (2007) find that income predicts conservative voting more strongly in the United States than in most European countries-a surprise to those of us weaned on the musings of Sombart (1906), Hartz (1955), and others about why the class war did not survive the Atlantic crossing. Huber and Stanig attribute cross-national differences in voting to cross-national differences in policy: on issues of income redistribution, the Democratic and Republican parties actually stand pretty far apart in comparison to the leftright differences in Europe.

The short version of this argument is that, in Europe, economic policy is off the table. The European welfare state is too expensive to expand and too popular to disband (see also Pierson, 1996). Left and right in Europe are thus reduced to fighting over "postmaterialist" issues in the sense of Inglehart (1971). These battles are commonly also about economics-most notably in debates about the extent to which immigrants can and should integrate with the majority in each country-but they do not lead to the same sort of income-based voting cleavages we see in the United States. In a cross-national analysis, Kenworthy and McCall (2007) find no relation between changes in market inequality and changes in the generosity of redistribution programs.

We see an intriguing connection between these international comparisons and the variation between states in American politics. When it comes to income and voting, the richer states of the northeast and west coast-but not those in the southern and central "heartland"-look more like Europe, with rich and poor voting similarly and Democratic and Republican voters separating themselves more on social than on economic issues.

\section{Discussion}

Higher-income Americans are more likely than low-income Americans to vote Republican. This gap-about 15 percentage points in recent years-is no surprise: these groups have differing economic interests, and the two major parties really do stand for different economic policies. 
The rise in income inequality in recent decades has heightened this gap in economic interests. In addition, the Democratic and Republican parties have moved farther apart on economic issues during this period (McCarty, Poole, and Rosenthal, 2006). One other piece of information to throw into the mix is that economics is paramount to voters. For example, in August 2008-a month before the financial meltdown-49\% said that economic issues such as job creation, gas prices, and the mortgage crisis should be the highest priority of government. An additional 14\% cited health care, which also manifests economic concerns. Only 37\% cited non-economic issues, such as Iraq, terrorism, and immigration (NBC/Wall Street Journal, 2008).

Rich and poor are more separated economically than they used to be, the two parties are more separated on economic policy than ever before, and economics remains voters' \#1 issue. So why do we find so little evidence of a link between income inequality and class-based voting?

One explanation for why inequality does not predict voting more strongly is tied into economic inequality itself: the argument is that the rich now have enough resources to tilt the political discourse in their direction and to even change the rules of the game (through campaign contributions and other forms of economic influence) in their favor. This explanation has been explored quantitatively by Ferguson (1995), McCarty, Poole, and Rosenthal (2006), and Bartels (2008), and more anecdotally by Frank (2004). Krugman (2007) and Galbraith (2008) come to similar conclusions when considering the impact of inequality from an economic perspective.

On the other hand, the victories of congressional Democrats in 2006 and Barack Obama in 2008 have reduced the appeal of arguments that the system is rigged against liberals. And even before these potentially transformative elections, Fiorina, Abrams, and Pope (2005) argued that neither the Democrats nor the Republicans represent the center of political gravity in the United States, a point given further support by Bafumi and Herron (2007), who estimate the ideological position of voters and congressmembers on a common scale and find the vast majority of voters to fall between the centers of the two parties' congressional delegations.

Income predicts vote choice about as well now as it did thirty years ago, but with a new geographic pattern. In poor states, income is associated with Republican voting much more than before, while in many rich states, the relation between income and vote choice is nearly zero. One key difference between red and blue America is in the relation between income and social attitudes: In Republican states, rich and poor have similar views on social issues. But in Democratic states, the rich are quite a bit more socially liberal than the poor. Factors such as religion and education result in a less clear pattern of class-based voting than we might expect based on income inequality alone. 


\section{REFERENCES}

Abramowitz Alan, and Ruy Teixeira. 2008. "The Decline of the White Working Class and the Rise of a Mass Upper-Middle Class". Pp. 109-46 in Ruy Teixeira eds., Red, Blue, and Purple America: The Future of Election Demographics. Washington, D.C.: Brookings Press.

Bafumi, Joseph, and Michael C. Herron. 2007. "Preference Aggregation, Representation, and Elected American Political Institutions." Department of Political Science, Dartmouth College. Available at <http://www.dartmouth.edu/ herron/RepInstitutions.pdf $>$.

Bartels, Larry M. 2006. "What's the matter with What's the Matter with Kansas?" Quarterly Journal of Political Science 1:201-216.

Bartels, Larry M. 2008. Unequal Democracy: The Political Economy of the New Gilded Age. New York: Princeton University Press.

Census Bureau. 2008. "Median Income for 4-Person Families, by State". Available at $<$ http://www.census.gov/hhes/www/income/4person.html>.

Dionne, E. J., Jr. 2005. "Polarized by God: American Politics and the Religion Divide". In Pietro S. Nivola and David W. Brady eds., Red and Blue Nation? Characteristics and Causes of America's Polarized Politics. Washington, D.C.: Brookings Institution Press.

Ferguson, Thomas. 1995. Golden Rule: The Investment Theory of Party Competition and the Logic of Money-Driven Political Systems. Chicago: University of Chicago Press.

Fiorina, Morris P., Samuel J. Abrams, and Jeremy Pope. 2005. Culture War? The Myth of a Polarized America. New York: Pearson Longman.

Frank, Robert H., and Philip J. Cook. 1996 The Winner-Take-All Society: Why the Few at the Top Get So Much More Than the Rest of Us. Penguin.

Frank, Thomas. 2004. What's the Matter with Kansas? How Conservatives Won the Heart of America. New York: Metropolitan Book.

Galbraith, James K. 2008. The Predator State: How Conservatives Abandoned the Free Market and Why Liberals Should Too. New York: Free Press.

Gelman, Andrew, David Park, Boris Shor, and Jeronimo Cortina. 2009. Red State, Blue State, Rich State, Poor State: Why Americans Vote the Way They Do, 2nd ed. New York: Princeton University Press.

Gelman, Andrew, Boris Shor, David Park, and Bafumi Joseph. 2007. "Rich State, Poor State, Red State, Blue State: What's the Matter with Connecticut?" Quarterly Journal of Political Science 2, 345-367. 
Gottschalk, Peter, and Sheldon Danziger. 2005. "Inequality of Wage Rates, Earnings, and Family Income in the United States, 1975-2002". Review of Income and Wealth 51(2):231-54.

Hartz, Louis. 1955. The Liberal Tradition in America: An Interpretation of American Political Thought since the Revolution. New York: Harcourt.

Huber, John D., and Piero Stanig. 2007. "Why Do the Poor Support Right-Wing Parties? A Cross-National Analysis". Department of Political Science, Columbia University.

Inglehart, Ronald 1971. "The Silent Revolution in Europe: Intergenerational Change in PostIndustrial Societies”. American Political Science Review 65(4):991-1017.

Kaus, Mickey. 1995. The End of Equality 2nd ed. New York: Basic Books.

Kenworthy, Lane, and Leslie McCall. 2008. "Inequality, Public Opinion and Redistribution." Socio-Economic Review 6(1):35-68.

Krugman, Paul R. 2007. The Conscience of a Liberal. New York: W.W. Norton \& Co.

McCarty, Nolan M., Keith T. Poole, and Howard Rosenthal. 2006. Polarized America: The Dance of Ideology and Unequal Riches. Cambridge, MA: MIT Press.

Mishel, Lawrence, Jared Bernstein, and Heidi Shierholz. 2009. The State of Working America 2008-2009. Ithaca, NY: ILR Press.

NBC/Wall Street Journal. 2008. Results from survey conducted 15-18 August. Available at $<$ http://www.pollingreport.com/prioriti.htm>.

Pierson, Paul. 1996. “The New Politics of the Welfare State”. World Politics 48(2):143-79.

Piketty, Thomas and Emmanuel Saez. 2007. Income and Wage Inequality in the United States, 1913-2002. Pp. 141-225 in A. B. Atkinson and Thomas Piketty eds., Top Incomes over the Twentieth Century: A Contrast between European and English-Speaking Countries. Oxford: Oxford University Press.

Sombart, Werner. 1906. Why Is There No Socialism in the United States? Translated 1976 by Patricia M. Hocking and C. T. Husbands. Armonk, NY: M. E. Sharpe. 


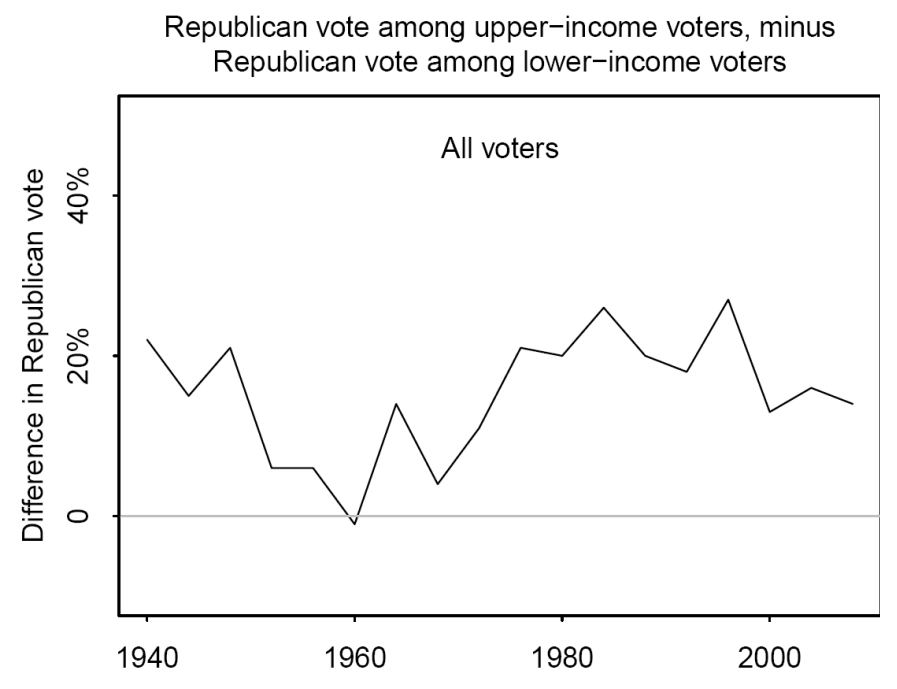

FIGURE 1. Republican vote share for president among voters in the upper third of income, minus Republican vote share among voters in the lower third. Data for 1940 and 1944 from Gallup Poll data compiled by Adam Berinsky and Tiffany Washburn; 1948-2004 from National Election Study cumulative data file, 2008 from Pew Research pre-election polls. 

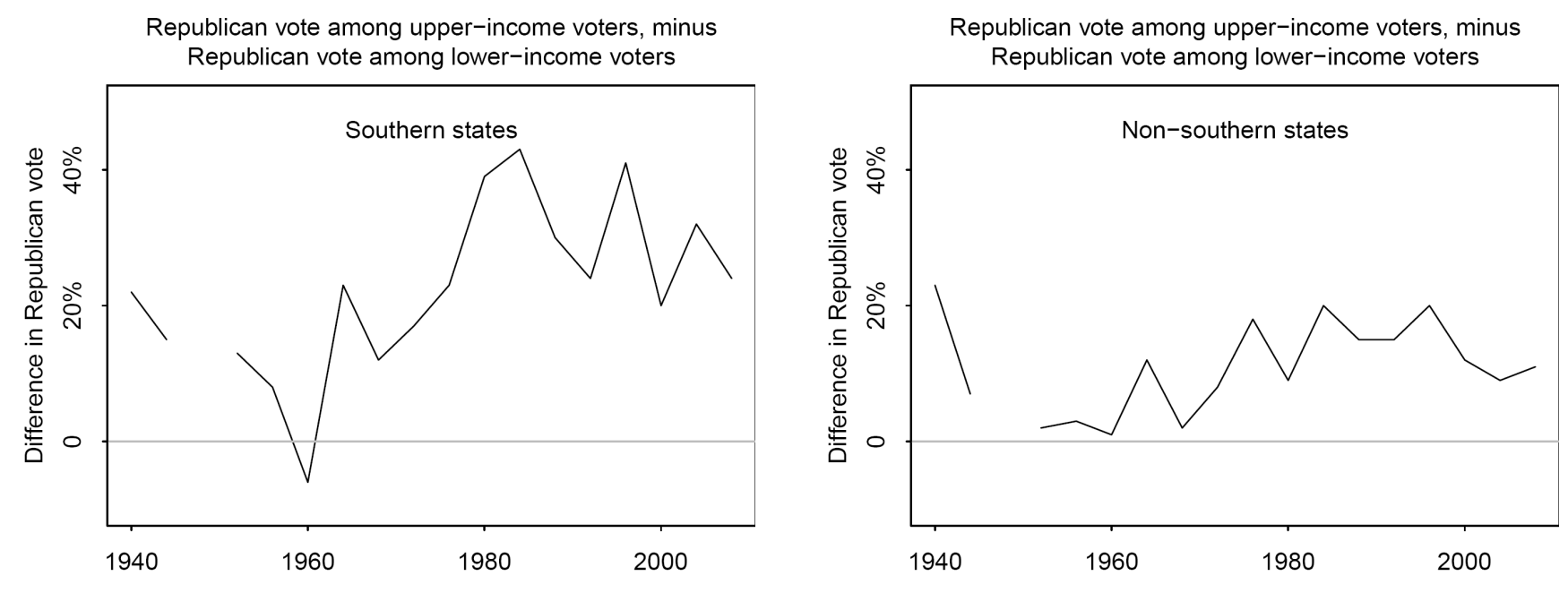

FIGURE 2. Republican vote share for president among voters in the upper third of income, minus Republican vote share among voters in the lower third, looking separately at southern and non-southern states. (For 1948 we had no survey data with both state and income.) 

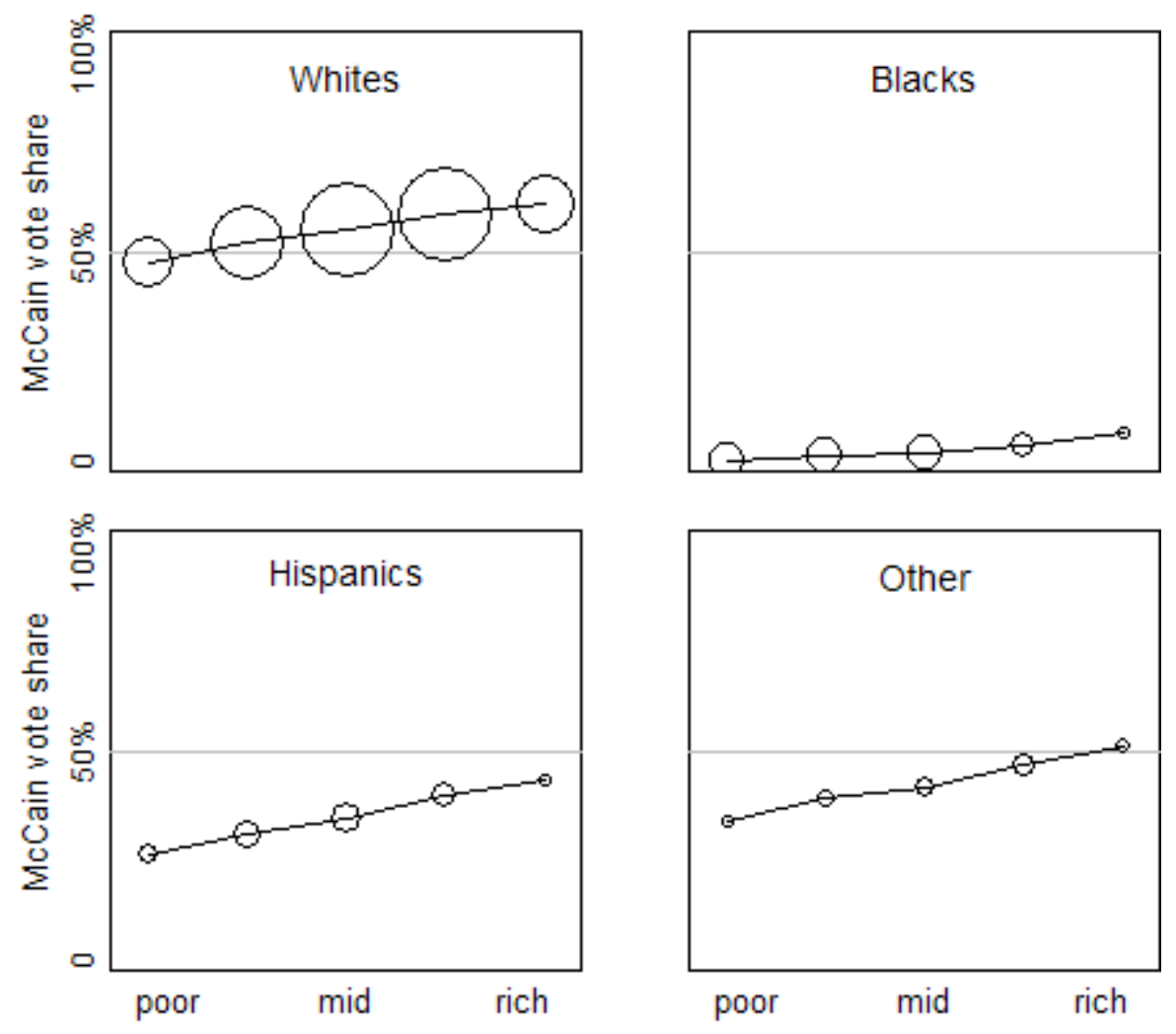

FIGURE 3. John McCain's share of the two-party vote share by income, among different ethnic groups, as estimated from a model fit to Pew Research Center polls conducted during the campaign. The income categories correspond to family income below $\$ 20,000, \$ 20-40,000, \$ 40-75,000, \$ 75-150,000$, and above $\$ 150,000$. We saw similar patterns in 2000 and 2004 exit polls. The area of each circle is proportional to the number of voters in the category. 

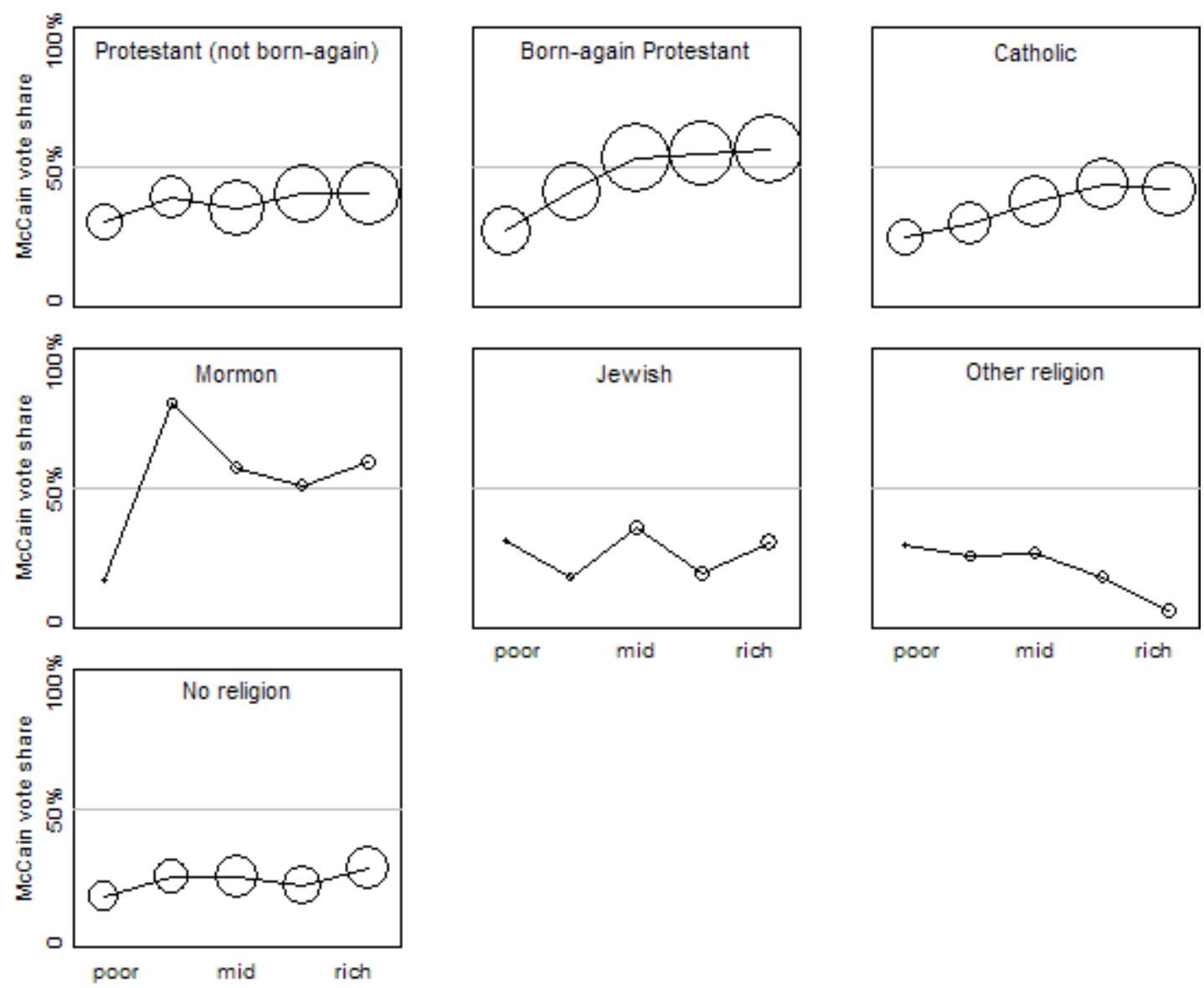

FIGURE 4. John McCain's share of the two-party vote share by income, among different religious groups, as estimated from Pew Research Center polls conducted during the campaign. For the largest religious groups, higher-income voters were more likely to vote Republican. We saw similar patterns in 2000 and 2004. The area of each circle is proportional to the number of voters in the category. Due to sample size limitations, it is difficult to draw strong conclusions about the smaller religious categories. 
U.S. House: Republican vote among rich voters minus Republican vote among poor voters
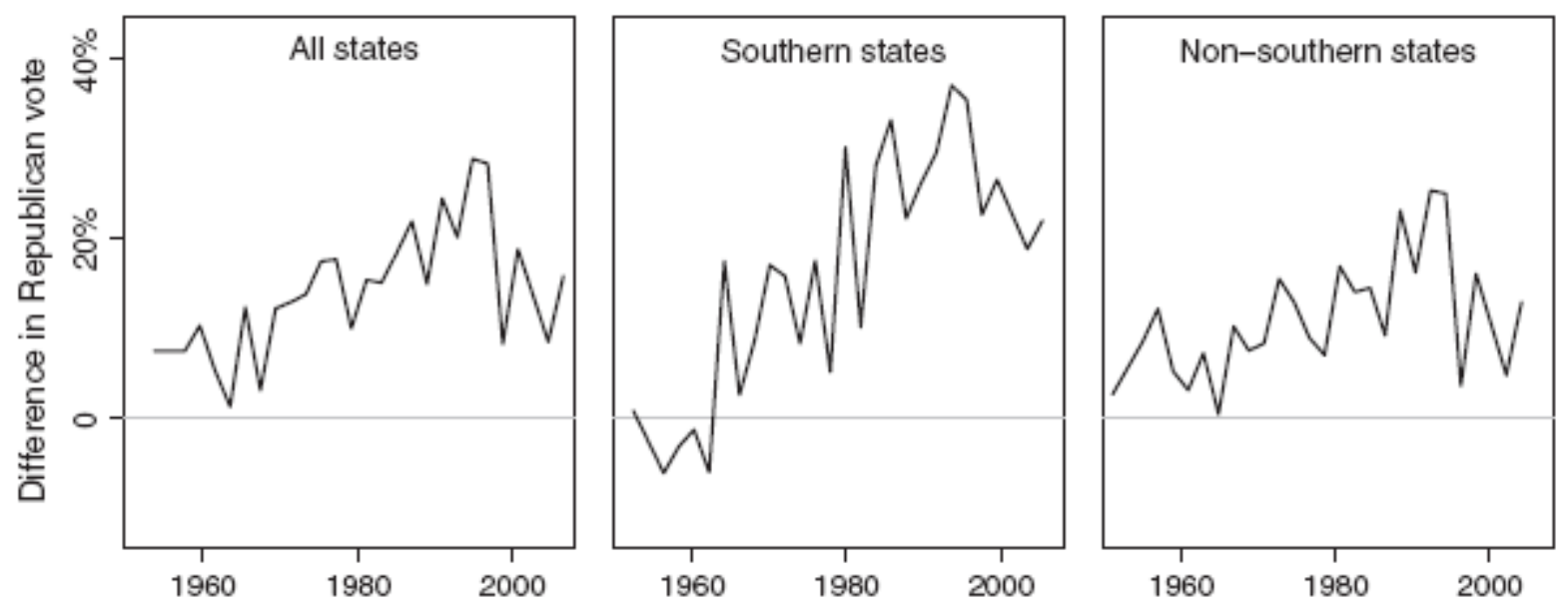

FIGURE 5. Republican vote share for the House of Representatives among voters in the upper third of income, minus Republican vote share among voters in the lower third, displayed for each election from 1952 to 2006. The pattern is very similar to the trend from 1952 onward in presidential elections, as shown in Figures 1 and 2. 

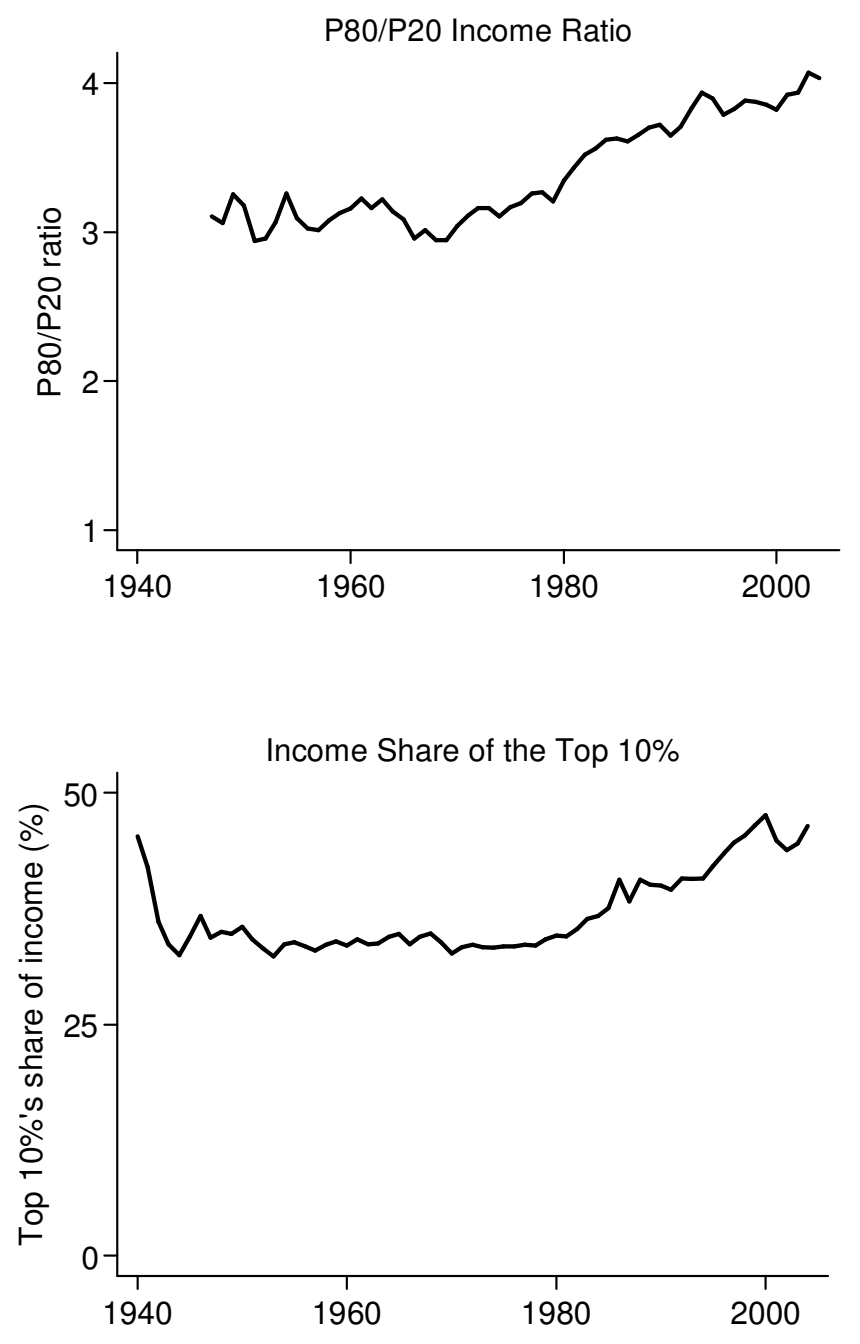

FIGURE 6. Income inequality, 1940 to 2004. The first chart uses Census Bureau data, from the Current Population Survey (CPS). Inequality is measured as the ratio of family income at the 80th percentile of the distribution to income at the 20th percentile. This time series begins in 1947. The second chart uses tax data, analyzed by Thomas Piketty and Emmanuel Saez (2008). Inequality is measured as the share of income going to the top $10 \%$ of taxpaying units. Both charts use pretax income. 
Group 1: states in which income inequality was flat or declining

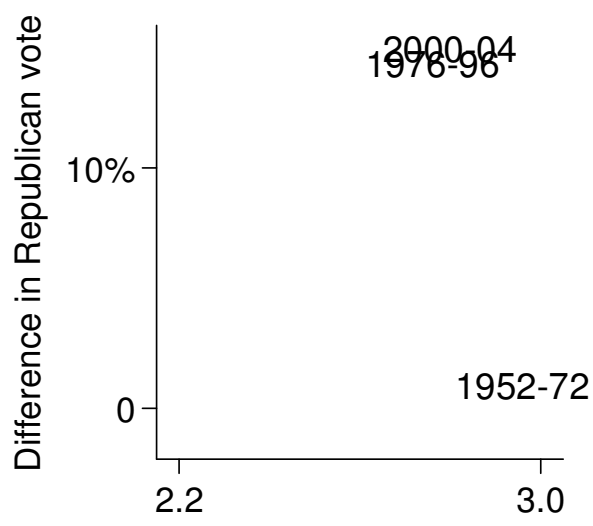

Group 2: states in which income inequality increased moderately

Group 3: states in which income inequality increased sharply

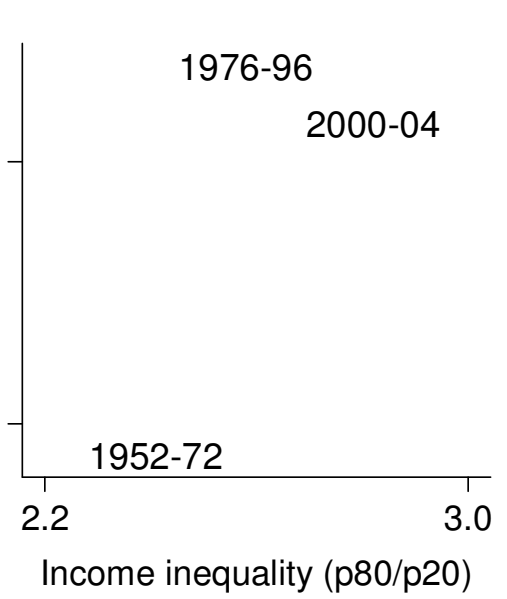

1976-96

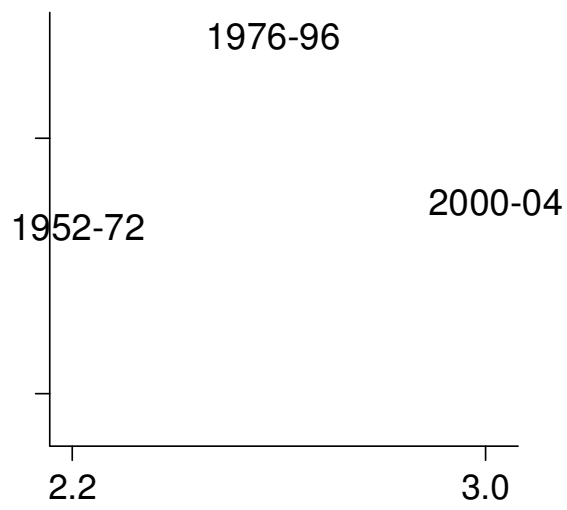

FIGURE 7. Income-based partisanship (difference in Republican vote share, comparing people in the upper and lower third of incomes), plotted against within-state income inequality (ratio of eightieth to twentieth percentiles of family income), for three time periods. The three graphs pool data from states in which income inequality was flat or declined, increased moderately, or increased sharply. Within each graph, the three periods represent the postwar boom (1952-1972), the subsequent period of stagnation (1976-1996), and the first elections of the twenty-first century (2000-2004). There is no clear relation between income partisan polarization and within-state income inequality.

States in group 1: AL, AR, GA, IA, KY, LA, MN, MS, MO, NE, NM, NC, ND, OK, SC, SD, TN, VT, VA, WI, WV. States in group 2: DE, FL, HI, IN, KS, ME, MD, MI, MT, NV, NH, OH, OR, PA, TX, UT, WY. States in group 3: AZ, CA, CO, CT, ID, IL, MA, NJ, NY, RI, WA. 


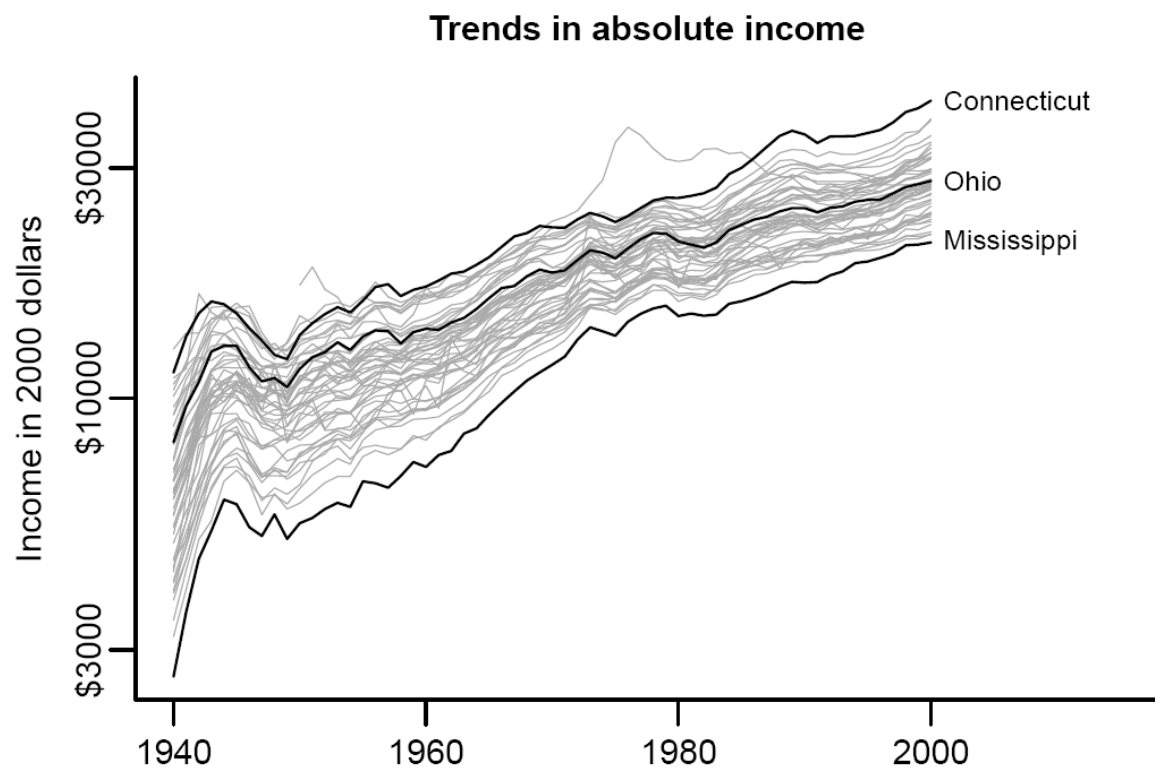

FIGURE 8. Average income by state (adjusted for inflation) over most of the past century. Each line on the graph shows a different state. The relative positions of the states have changed little. Incomes grew faster in poorer states from 1940 to around 1980. Since then the gap has held steady. 


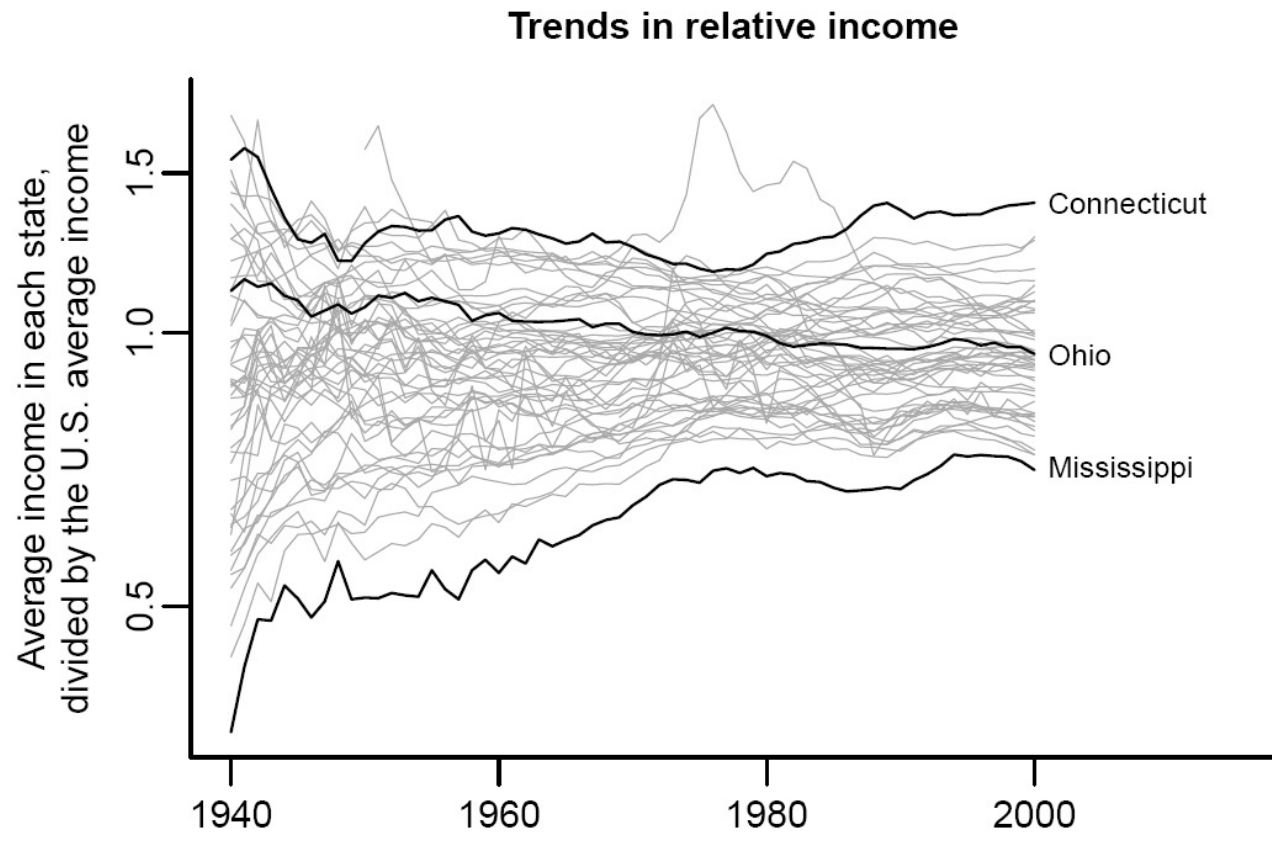

FIGURE 9. Trends in relative state incomes. The gap between rich and poor states narrowed until about 1980 but has remained steady or widened since then. (The state whose per capita income jumped so high in the 1970s is Alaska.) 


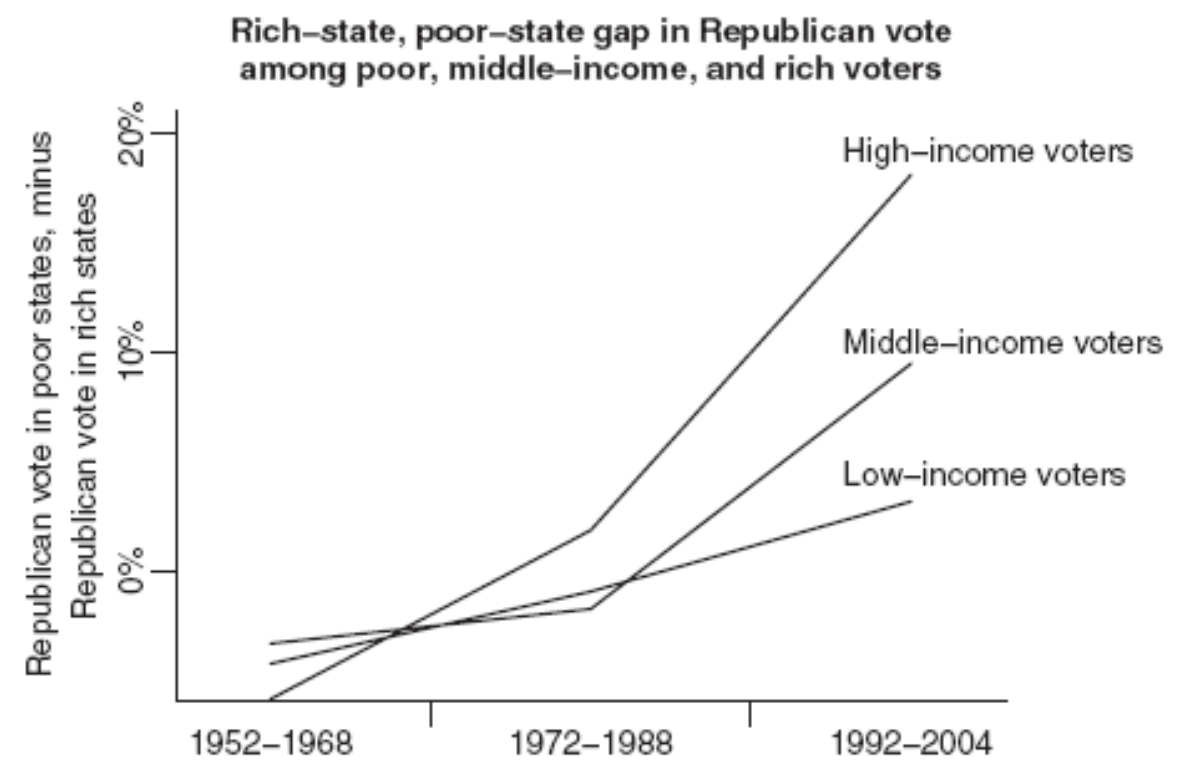

FIGURE 10. Democrats win rich states and Republicans win poor states, but it didn't used to be that way. The voting gap between rich and poor states has opened up among rich voters but much less so among the poor, even when looking only at whites. From Gelman et al. (2009). 
Whites only: Rich-state, poor-state gap in Republican vote among poor, middle-income, and rich voters

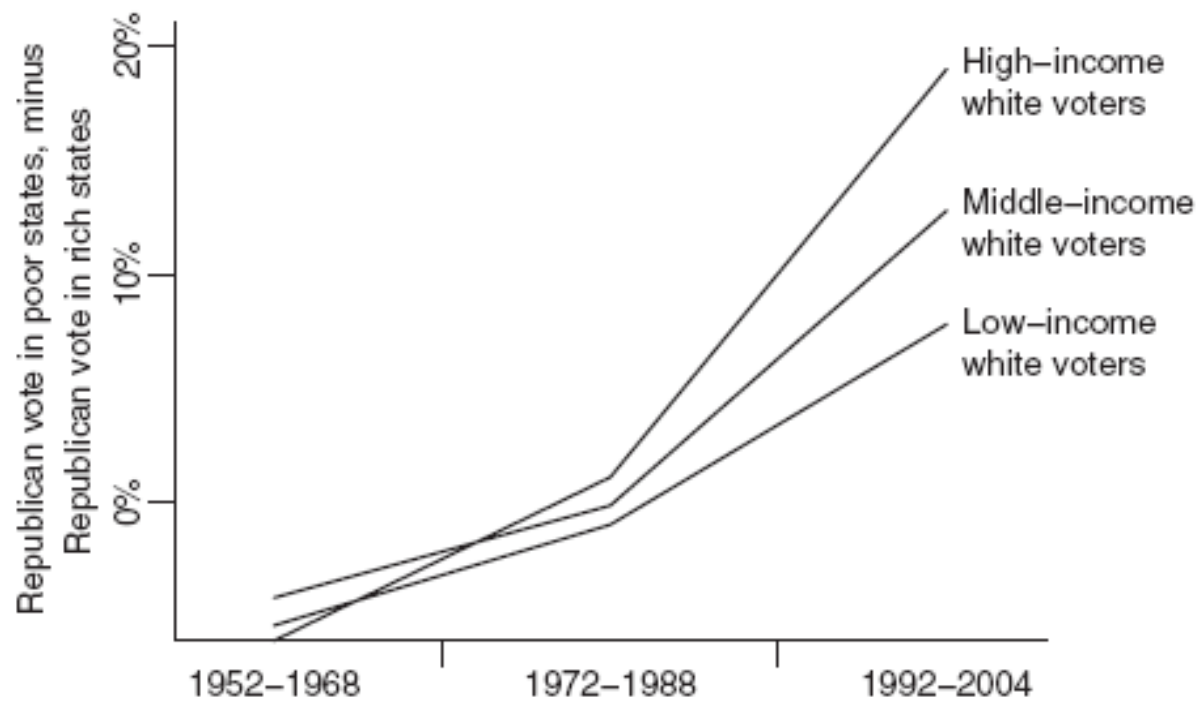

FIGURE 11. The voting gap between rich and poor states has opened up among rich voters but much less so among the poor, even when looking only at whites. From Gelman et al. (2009). 
Trends in 90th and 10th percentile of income within each state, 1963-2004

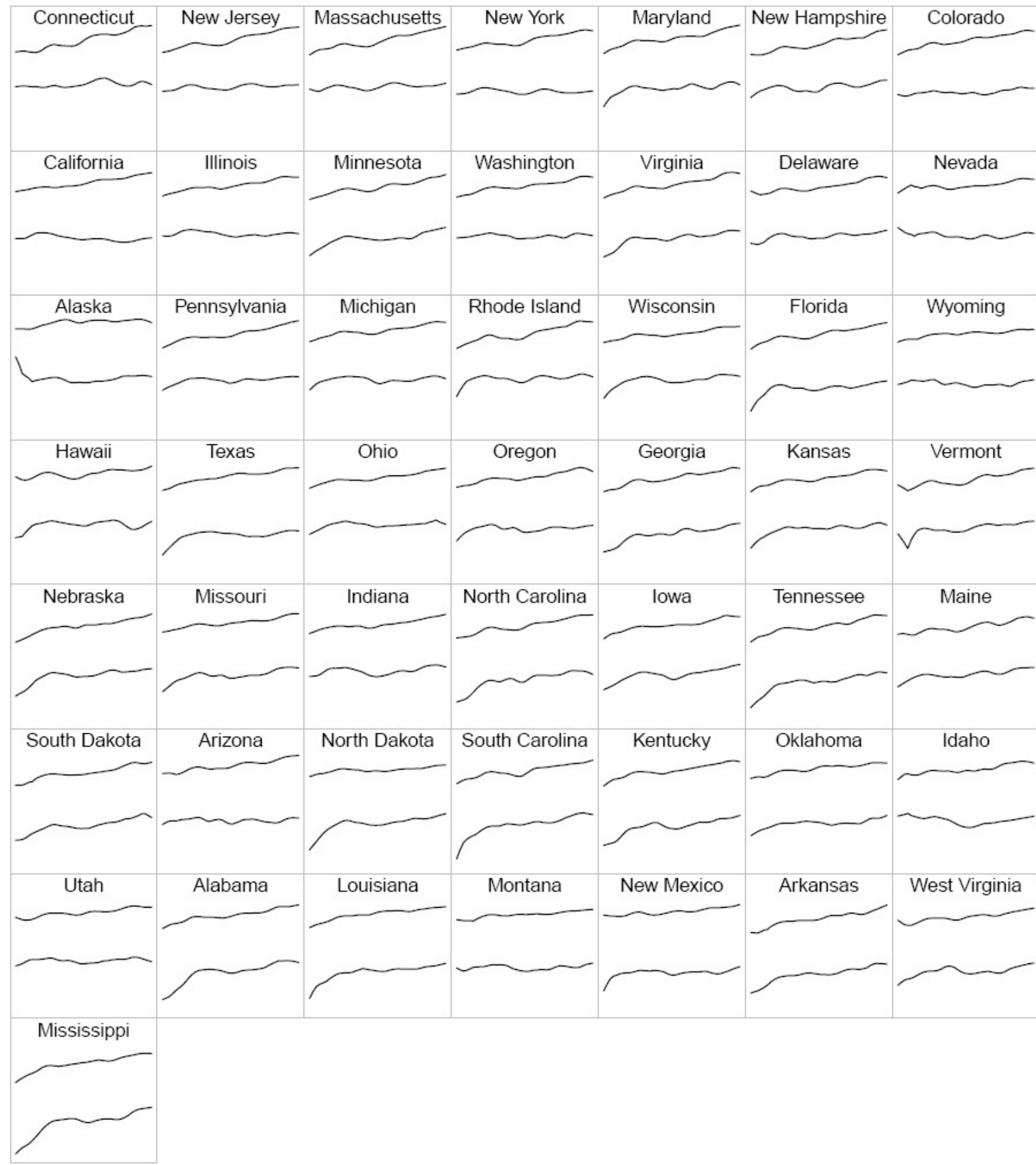

FIGURE 12. Forty-year trends in incomes of ninetieth and tenth percentiles within each state. The graphs are on a common logarithmic scale running from $\$ 2,000$ to $\$ 125,000$ in inflation-adjusted dollars, with states ordered from richest to poorest. Incomes at the 90th percentile in richer states not only are higher than in poorer ones, but they have been growing quite rapidly in recent decades. 